\title{
Study on the applicability of potentially probiotic strain Lactobacillus plantarum L4 to be included in the development of strategies for bio-preservation of food products
}

\author{
Zapryana Denkova ${ }^{1}$, Bogdan Goranov ${ }^{1}$, Rositsa Denkova-Kostova ${ }^{2, *}$, Pascal Degraeve ${ }^{3}$, Georgi Kostov $^{4}$, and \\ Nadia Oulahal ${ }^{3}$ \\ ${ }^{1}$ Department of Microbiology, University of Food Technologies, Plovdiv, Bulgaria \\ ${ }^{2}$ Department of Biochemistry and Molecular Biology, University of Food Technologies, Plovdiv, Bulgaria \\ ${ }^{3}$ BioDyMIA (Bioengineering and Microbial Dynamics at Food Interfaces) Université Lyon 1- ISARA Lyon Joined Research Unit, \\ Université de Lyon, Bourg en Bresse, France \\ ${ }^{4}$ Department of Wine and Beer Technology, University of Food Technologies, Plovdiv, Bulgaria
}

\begin{abstract}
The antimicrobial activity of potentially probiotic strains is important for their possible application in the development of successful strategies for bio-preservation of different foods. The antimicrobial activity of the potentially probiotic strain Lactobacillus plantarum L4 against the pathogenic bacteria Salmonella abony; Staphylococcus aureus; Escherichia coli and the phytopathogenic fungi Aspergillus niger and Aspergillus flavus was determined using agar-diffusion assay with wells. Lb. plantarum L4 exhibited high antagonistic activity against all test microorganisms included in the study, which was due not only to the production and accumulation of lactic acid and other organic acids, but also to the production of other bioactive substances. The bioactive substances were then submitted to the action of different enzymes. This allowed to observe that they have protein nature, suggesting that they are likely bacteriocins or bacteriocin-like substances. The substances produced by $L b$. plantarum L4 did not lose their antimicrobial activity during heat treatment at temperatures above $100{ }^{\circ} \mathrm{C}$ for 15 min and they exhibited high inhibitory activity against the test-microorganisms when pH ranged between 4 and 7 . After further examination of the properties of the produced antimicrobial compounds, Lb. plantarum L4 can be used in the development of strategies for bio-preservation of different food products.
\end{abstract}

\section{Introduction}

Interest in food bio-preservation has considerably increased in the last decades due to the proven adverse effects of chemical preservatives on human health [1]. Indeed, finding natural antimicrobial agents with significant antimicrobial activity has received considerable attention to enhance the quality and shelflife of a food product [2]. Well-characterized bacterial peptides with antimicrobial activity, referred to as bacteriocins, have been utilized in various sectors such as the food industry and medicine [1].

Bio-preservation is a method for preserving the quality of food and prolonging its shelf life by introducing substances of plant origin or microorganisms (most often lactobacilli and bifidobacteria), producing metabolites with high antimicrobial activity [3].

Bacteria and yeasts used in food production produce various compounds with antimicrobial activity, such as organic acids (lactic acid, acetic acid, propionic acid), diacetyl, $\mathrm{H}_{2} \mathrm{O}_{2}$, reuterin, bacteriocins and enzymes that exhibit bacteriostatic, bactericidal, fungistatic and fungicidal action against spoilage microorganisms and pathogens. They differ in the mode of antimicrobial action. Since they are produced by GRAS- microorganisms, they can be used as food biopreservatives for bio-preservation of food and beverages [4].

To ensure food safety, substances with antimicrobial action can be imported as pure substances or as viable cells of microbial strains that grow in food and release these metabolites in the food. Bacteriocins of lactic acid bacteria are currently used as biopreservatives but also living cells of lactobacilli and lactic acid cocci themselves are directly added into food products [3].

The antimicrobial action of lactic acid bacteria is mainly related to the production of lactic acid and acetic acid. The production of propionic acid, sorbic acid, benzoic acid, hydrogen peroxide, diacetyl, ethanol, phenolic and protein compounds has been established. By producing organic acids, lactic acid bacteria alter the $\mathrm{pH}$ of the medium and inhibit the growth of putrefactive pathogens, toxigenic microorganisms or act directly on microbial cells through antibacterial substances of a peptide nature (bacteriocins) [4]. Bacteriocins of food lactic acid bacteria are considered safe food biopreservatives and have the potential to be used to kill sensitive Gram-positive spoilage food bacteria and food pathogens. In foods that may contain damaged Gram-

\footnotetext{
* Corresponding author: rositsa denkova@mail.bg
} 
negative bacteria, bacteriocins can also be used effectively to kill them.

Lactic acid bacteria bacteriocins have a number of advantages that make them promising for application in successful strategies for food bio-preservation: lactic acid bacteria are implicated in food fermentations for centuries and have proven history of safety, thereby their metabolites are generally recognized as safe; none of the lactic acid bacteria bacteriocins have shown any toxic effect against eukaryotic cells; the proteinaceous nature of bacteriocins ensures their safety as they become inactive by digestive proteases [2].

Often, bacteriocin can be used either directly or alongside other treatment methods depending on the reason of usage and the nature of the very food [5]. Lactic acid bacteria bacteriocins are applied as an additive since they are known to satisfy industrial and consumer demands for minimally processed and fresh foods $[1,6]$.

The aim of the present study was to investigate the in vitro antimicrobial activity of the potentially probiotic strain $L b$. plantarum L4 against pathogenic bacteria and phytopathogenic fungi and to investigate the biomolecules causing the observed antimicrobial action of the studied strain.

\section{Materials and methods}

\subsection{Microorganisms}

The studies in the present work were performed with the potentially probiotic strain $\mathrm{Lb}$. plantarum L4, isolated from fermented vegetables.

The following test microorganisms were used: Salmonella abony NTCC 6017, Escherichia coli ATCC 8739, Staphylococcus aureus ATCC 6538P, Aspergillus niger ATCC 20611, Aspergillus flavus ATCC 16872. The strains were grown on LBG-agar medium at $37^{\circ} \mathrm{C}$.

\subsection{Methods of analysis}

\subsubsection{Preparation of cell-free supernatant}

Lactobacillus plantarum L4 was cultured in MRS broth for $48 \mathrm{~h}$. The culture medium was centrifugated at 3500xg for $10 \mathrm{~min}$. The supernatants were decanted and the $\mathrm{pH}$ was adjusted to $\mathrm{pH}=6.5$ with $\mathrm{NaOH}\left(1 \mathrm{~mol} / \mathrm{dm}^{3}\right)$ to eliminate the effect of acidity. Then the sample was filtered through filters with a pore diameter of $0.20 \mu \mathrm{m}$ (Sartorius, Minisart ${ }^{\circledR}$, Göttingen, Germany) [7, 8].

\subsubsection{Antimicrobial activity of lactobacilli against pathogenic bacteria and fungi - agar diffusion method with wells}

Suspensions with a concentration of viable cells (for bacteria) or of spores (for fungi) above $10^{7} \mathrm{cfu} / \mathrm{cm}^{3}$ were prepared from pathogenic bacteria cultures ( $24 \mathrm{~h}$ cultures) and from fungi (well sporulated cultures for 5-7 days). A certain amount of these suspensions was introduced into the molten agar media and cooled to $45^{\circ} \mathrm{C}$ solid medium so that the effective concentration of viable pathogenic cells or fungal spores exceeded $10^{5} \mathrm{cfu} / \mathrm{cm}^{3}$. After thorough mixing and solidification, $20 \mathrm{~cm}^{3}$ of the medium were poured into sterile Petri dishes. After the medium has solidified, wells $(\mathrm{d}=6 \mathrm{~mm})$ were prepared with a sterile stopper. $5 \times 10^{-2} \mathrm{~cm}^{3}$ of the filtered cell-free supernatant of $L b$. plantarum L4 (in two replicates) was pipetted onto the surface or the solidified medium. The plates were left at room temperature for $1 \mathrm{~h}$ for prediffusion of the cell-free supernatants into the agar, then incubated at $37^{\circ} \mathrm{C}$ for $24 \mathrm{~h}$ for pathogenic bacteria and $30^{\circ} \mathrm{C}$ for $24 \mathrm{~h}$ to $48 \mathrm{~h}$ for fungi.

The results are reported depending on the inhibition zone formed. Antimicrobial activity was determined by measuring the diameter of the inhibition zones around the wells $[7,8]$.

The test-microorganisms were: S. abony NTCC 6017; S. aureus ATCC 6538 P; E. coli ATCC 8739 and phytopathogenic fungi of the genus Aspergillus (A. niger ATCC 20611, A. flavus ATCC 16872), whose concentrations of viable cells (for bacteria) or concentrations of the spore suspensions (for the fungi) are listed in Table 1.

Table 1. Concentrations of viable cells of the testmicroorganisms.

\begin{tabular}{|l|c|}
\hline \multicolumn{1}{|c|}{ Strain } & $\begin{array}{c}\text { Concentration of viable } \\
\text { cells, } \mathbf{c f u} / \mathbf{c m}^{\mathbf{3}}\end{array}$ \\
\hline S. abony NTCC 6017 & $5.2 \times 10^{9}$ \\
\hline E. coli ATCC 8739 & $9.0 \times 10^{8}$ \\
\hline S. aureus ATCC 6538 P & $3.0 \times 10^{9}$ \\
\hline A. niger ATCC 20611 & $1.1 \times 10^{5}$ \\
\hline A. flavus ATCC 16872 & $2.2 \times 10^{5}$ \\
\hline
\end{tabular}

\subsubsection{Sensitivity of cell-free supernatants to changes in the $\mathrm{pH}$, enzyme and heat treatment}

The effect of $\mathrm{pH}$ on bacteriocins was determined by preparing samples through changing the $\mathrm{pH}$ of the cellfree supernatants to $\mathrm{pH}=4.0, \mathrm{pH}=5.0, \mathrm{pH}=6.0, \mathrm{pH}=7.0$ and $\mathrm{pH}=8.0$ with sterile $1 \mathrm{~N} \mathrm{NaOH}$. After incubation for 2 $\mathrm{h}$ at room temperature, the $\mathrm{pH}$ of all samples was adjusted to $\mathrm{pH}=6.5$ with sterile $1 \mathrm{~N} \mathrm{NaOH}$ or $1 \mathrm{~N} \mathrm{HCl}$ and the antimicrobial activity of the processed cell-free supernatants was determined by the agar-diffusion method with wells.

For the enzyme treatment, $1.5 \mathrm{~cm}^{3}$ of the cell-free supernatants were incubated for $1 \mathrm{~h}$ in the presence of 1 $\mathrm{mg} / \mathrm{cm}^{3}$ (final concentration) of trypsin, papain, proteolytic complex of Bacillus 5860, proteolytic complex of Bacillus 3111, alkalase, lipase or $\alpha$-amylase. After the enzymatic reactions were stopped by heating at $80^{\circ} \mathrm{C}$ for $10 \mathrm{~min}$, the antimicrobial activity of the processed cell-free supernatants was determined by the agar-diffusion method with wells.

For the heat treatment, the cell-free supernatants were heated in a water bath at temperatures ranging from $30^{\circ} \mathrm{C}$ to $100^{\circ} \mathrm{C}$ (with the temperature variation step being $10^{\circ} \mathrm{C}$ ), for $1 \mathrm{~h}$ or autoclaved (at $121^{\circ} \mathrm{C}$ ) for $15 \mathrm{~min}$ and the antimicrobial activity of the processed cell-free supernatants was determined by the agar-diffusion method with wells. 
For this purpose, the enzymatic reactions shown in Table 2 were performed [9].

Table 2. Enzymatic reactions for determining the protein nature of the substances produced by $L b$. plantarum L4.

\begin{tabular}{|c|c|c|c|}
\hline № & Enzymes & Reaction & $\begin{array}{l}\text { Reaction } \\
\text { stopping }\end{array}$ \\
\hline 1. & Proteolytic & & \\
\hline 1.1. & Trypsin & \multirow{5}{*}{$\begin{array}{l}37^{\circ} \mathrm{C} ; \\
60 \mathrm{~min} ; \\
\mathrm{pH}=8.0 \\
\mathrm{pH}=7.0\end{array}$} & \multirow{5}{*}{$\begin{array}{l}\text { Heat treatment } \\
\text { at } 80^{\circ} \mathrm{C} \\
\text { for } 10 \mathrm{~min}\end{array}$} \\
\hline 1.2 . & Papain & & \\
\hline 1.3 . & $\begin{array}{l}\text { Proteolytic } \\
\text { complex } \\
\text { Bacillus } 5860\end{array}$ & & \\
\hline 1.4 . & $\begin{array}{l}\text { Proteolytic } \\
\text { complex } \\
\text { Bacillus } 3111\end{array}$ & & \\
\hline 1.5 . & Alkalase & & \\
\hline 2. & Non-proteolytic & & \\
\hline 2.1 . & $\alpha$-amylase & $\begin{array}{l}30^{\circ} \mathrm{C} ; \\
60 \mathrm{~min} ; \\
\mathrm{pH}=4.7\end{array}$ & $\begin{array}{l}\text { Heat treatment } \\
\text { at } 80^{\circ} \mathrm{C} \\
\text { for } 10 \mathrm{~min}\end{array}$ \\
\hline 3. & Lipolytic & & \\
\hline 3.1 . & Lipase & $\begin{array}{l}37^{\circ} \mathrm{C} \\
60 \mathrm{~min} \\
\mathrm{pH}=7.0\end{array}$ & $\begin{array}{l}\text { Heat treatment } \\
\text { at } 80^{\circ} \mathrm{C} \\
\text { for } 10 \mathrm{~min}\end{array}$ \\
\hline
\end{tabular}

\subsection{Processing of the results}

Data from triplicate experiments were processed with MS Office Excel 2010 software products, using statistical functions to determine the standard deviation and the maximum estimation error at significance levels of $p<$ 0.05 .

\section{Results and discussion}

Most bacteriocins of lactobacilli and lactic acid cocci are short peptides. Therefore, in a series of experiments the supernatants obtained after the growth of the potentially probiotic strain $L b$. plantarum L4 were tested for the presence of substances with antimicrobial activity and protein nature in the supernatants.

The inhibitory activity of the samples obtained after the enzymatic treatment of the cell-free supernatants against pathogenic bacteria was determined (Table 3 ).

The experimental data presented in Table 3 unequivocally show that $\mathrm{Lb}$. plantarum L4 demonstrated high antimicrobial activity against pathogenic bacteria and phytopathogenic fungi. Since the acidity as an inhibitory factor had been eliminated, this suggested that the observed inhibitory effect could be due to the synthesis of substances of protein nature, secreted in the medium and bound to the cell surface (Table 3 ).

The inactivation of the substances with antimicrobial action by proteolytic enzymes, while at the same time retaining their activity upon exposure to $\alpha$-amylase and lipase, confirmed the protein nature of those substances and that the inhibition zones were not due only to the production of organic acids. Similar studies and observations have been cited by Todorov and Dicks [10] and Mezaini et al. [11].
The resistance of the substances produced by the potentially probiotic strain Lactobacillus plantarum L4 to different temperatures has also been examined. The temperature treatment was carried out at temperatures from $30^{\circ} \mathrm{C}$ to $121^{\circ} \mathrm{C}$. The experimental data from these studies are reflected in Table 4.

Experimental data show that the bacteriocins or bacteriocin-like substances formed by $\mathrm{Lb}$. plantarum L4 were temperature resistant and although it changes below $70^{\circ} \mathrm{C}$, these substances retain activity against pathogens up to $121^{\circ} \mathrm{C}$ (Table 4). However, it is probable that at temperature treatment below $70^{\circ} \mathrm{C}$ slight changes in the protein structure occur, which lead to a decrease in the antimicrobial action, especially against pathogenic bacteria (Table 4).

The effect of $\mathrm{pH}$ on the antimicrobial activity of the bacteriocins secreted in the culture medium by Lactobacillus plantarum L4 was also studied (Table 5).

The highest antimicrobial activity of bacteriocins produced by Lactobacillus plantarum L4 against the testpathogenic bacteria Salmonella abony NTCC 6017; Staphylococcus aureus ATCC 6538 P; Escherichia coli ATCC 8739 was determined in the $\mathrm{pH}$ range of $\mathrm{pH}=4.0$ to $\mathrm{pH}=7.0$ (Table 5). The results for the phytopathogenic fungi of the genus Aspergillus (A. niger ATCC 20611, A. flavus ATCC 16872) were similar. In the alkaline $\mathrm{pH}$ range the bacteriocin lost its inhibitory activity. Nevertheless, the bacteriocins or bacteriocin-like substances remain stable under the $\mathrm{pH}$ conditions that predominate in most food matrices.

This in turn reveals opportunities for its application in the production of fermented foods, probiotics and probiotic foods as food biopreservatives.

\section{Conclusions}

Lb. plantarum L4 strain with probiotic potential exhibited high antimicrobial activity against the test-pathogenic bacteria S. abony NTCC 6017; S. aureus ATCC 6538 P; E. coli ATCC 8739 and phytopathogenic fungi of the genus Aspergillus (A. niger ATCC 20611, A. flavus ATCC 16872), the degree of inhibition being species- and strain-specific. The inhibitory action of Lb. plantarum L4 was found to result from the secretion into the culture medium of substances of a protein nature with antimicrobial activity (likely bacteriocins or bactericinlike substances). The bacteriocin(s) produced by Lactobacillus plantarum L4 has/have been shown to be temperature resistant and did not lose its antimicrobial activity when treated above $100^{\circ} \mathrm{C}$ for $15 \mathrm{~min}$ ). The bacteriocin or bacteriocin-like substances, produced by Lb. plantarum L4, exhibited a high degree of inhibition against pathogenic bacteria and phytopathogenic fungi in the $\mathrm{pH}$ range of $\mathrm{pH}=4.0$ to $\mathrm{pH}=7.0$. This in turn reveals opportunities for its application in the production of fermented foods, probiotics and probiotic foods as food biopreservatives. 
Table 3. Antimicrobial activity of enzymatically treated cell-free supernatants of $L b$. plantarum L4 against pathogenic bacteria and phytopathogenic fungi of the genus Aspergillus.

\begin{tabular}{|l|c|c|c|c|c|}
\hline \multirow{2}{*}{\multicolumn{1}{|c|}{ Enzyme }} & \multicolumn{5}{|c|}{ Inhibition zones, mm } \\
\cline { 2 - 6 } & $\begin{array}{c}\text { Salmonella } \\
\text { abony } \\
\text { NTCC 6017 }\end{array}$ & $\begin{array}{c}\text { Staphylococcus } \\
\text { aureus } \\
\text { ATCC 6538 P }\end{array}$ & $\begin{array}{c}\text { Escherichia } \\
\text { coli } \\
\text { ATCC 8739 }\end{array}$ & $\begin{array}{c}\text { Aspergillus } \\
\text { niger } \\
\text { ATCC 20611 }\end{array}$ & $\begin{array}{c}\text { Aspergillus } \\
\text { flavus } \\
\text { ATCC } 16872\end{array}$ \\
\hline trypsin & - & - & - & - & - \\
\hline papain & - & - & - & - & - \\
\hline proteolytic complex of Bacillus 5860 & - & - & - & - & - \\
\hline proteolytic complex of Bacillus 3111 & - & - & - & - & - \\
\hline alkalase & - & - & - & - & - \\
\hline$\alpha$-amylase & $12.17 \pm 0.24$ & $9.67 \pm 0.24$ & $9.67 \pm 0.24$ & $9.17 \pm 0.24$ & $9.17 \pm 0.24$ \\
\hline lipase & $13.50 \pm 0.41$ & $9.08 \pm 0.31$ & $9.00 \pm 0.41$ & $10.50 \pm 0.41$ & $14.00 \pm 0.41$ \\
\hline buffer with $\mathrm{pH}=8$ (control) & - & - & - & - & - \\
\hline buffer with $\mathrm{pH}=7$ (control) & - & - & - & - & - \\
\hline buffer with $\mathrm{pH}=4.7$ (control) & - & - & - & - & - \\
\hline supernatant $+\mathrm{dH} \mathrm{H}_{2} \mathrm{O}$ (control) & $10.17 \pm 0.24$ & $9.33 \pm 0.47$ & $9.17 \pm 0.24$ & $9.00 \pm 0.41$ & $10.17 \pm 0.24$ \\
\hline supernatant & $11.17 \pm 0.24$ & $10.08 \pm 0.31$ & $9.17 \pm 0.24$ & $13.17 \pm 0.24$ & $12.08 \pm 0.31$ \\
\hline culture medium & $14.08 \pm 0.31$ & $12.17 \pm 0.24$ & $13.50 \pm 0.41$ & $16.17 \pm 0.24$ & $15.17 \pm 0.24$ \\
\hline
\end{tabular}

$\mathrm{d}_{\text {well }}=6.0 \mathrm{~mm}$. Inhibition zones are zones with a $\mathrm{d}>7.0 \mathrm{~mm}$

Table 4. Inhibitory activity of supernatants of the potentially probiotic strain $L$ b. plantarum L4, treated at different temperatures, against pathogenic bacteria phytopathogenic fungi of the genus Aspergillus.

\begin{tabular}{|c|c|c|c|c|c|}
\hline \multirow{2}{*}{ Temperature, ${ }^{\circ} \mathbf{C}$} & \multicolumn{5}{|c|}{ Inhibition zones, mm } \\
\cline { 2 - 6 } & $\begin{array}{c}\text { Salmonella } \\
\text { abony } \\
\text { NTCC 6017 }\end{array}$ & $\begin{array}{c}\text { Staphylococcus } \\
\text { aureus } \\
\text { ATCC 6538 P }\end{array}$ & $\begin{array}{c}\text { Escherichia } \\
\text { coli } \\
\text { ATCC } 8739\end{array}$ & $\begin{array}{c}\text { Aspergillus } \\
\text { niger } \\
\text { ATCC 20611 }\end{array}$ & $\begin{array}{c}\text { Aspergillus } \\
\text { flavus } \\
\text { ATCC 16872 }\end{array}$ \\
\hline 30 & $10.17 \pm 0.24$ & $10.17 \pm 0.24$ & $12.33 \pm 0.47$ & $10.17 \pm 0.24$ & $10.33 \pm 0.47$ \\
\hline 40 & $10.33 \pm 0.47$ & $10.17 \pm 0.24$ & $12.17 \pm 0.24$ & $10.33 \pm 0.47$ & $10.17 \pm 0.24$ \\
\hline 60 & $10.17 \pm 0.24$ & $10.50 \pm 0.41$ & $10.67 \pm 0.24$ & $11.67 \pm 0.24$ & $10.33 \pm 0.47$ \\
\hline 70 & $10.50 \pm 0.41$ & $9.17 \pm 0.24$ & $10.67 \pm 0.24$ & $8.67 \pm 0.24$ & $8.67 \pm 0.24$ \\
\hline 80 & $9.67 \pm 0.24$ & $9.33 \pm 0.47$ & $10.17 \pm 0.24$ & $9.33 \pm 0.47$ & $9.17 \pm 0.24$ \\
\hline 90 & $10.33 \pm 0.47$ & $9.17 \pm 0.24$ & $10.33 \pm 0.47$ & $10.17 \pm 0.24$ & $8.67 \pm 0.24$ \\
\hline 100 & $9.17 \pm 0.24$ & $8.17 \pm 0.24$ & $9.17 \pm 0.24$ & $10.33 \pm 0.47$ & $10.17 \pm 0.24$ \\
\hline 121 & $9.17 \pm 0.24$ & $8.33 \pm 0.47$ & $9.17 \pm 0.24$ & $10.17 \pm 0.24$ & $8.33 \pm 0.47$ \\
\hline
\end{tabular}

$\mathrm{d}_{\mathrm{well}}=6.0 \mathrm{~mm}$. Inhibition zones are zones with a $\mathrm{d}>7.0 \mathrm{~mm}$

Table 5. Effect of $\mathrm{pH}$ on the antimicrobial activity of bacteriocins produced by Lb. plantarum L4 against pathogenic bacteria and phytopathogenic fungi of the genus Aspergillus.

\begin{tabular}{|c|c|c|c|c|c|}
\hline $\mathbf{p H}$ value & \multicolumn{5}{|c|}{ Inhibition zones, mm } \\
\hline & $\begin{array}{c}\text { Salmonella } \\
\text { abony } \\
\text { NTCC 6017 }\end{array}$ & $\begin{array}{c}\text { Staphylococcus } \\
\text { aureus } \\
\text { ATCC 6538 P }\end{array}$ & $\begin{array}{c}\text { Escherichia } \\
\text { coli } \\
\text { ATCC } 8739\end{array}$ & $\begin{array}{c}\text { Aspergillus } \\
\text { niger } \\
\text { ATCC 20611 }\end{array}$ & $\begin{array}{c}\text { Aspergillus } \\
\text { flavus } \\
\text { ATCC } 16872\end{array}$ \\
\hline 4 & $10.17 \pm 0.24$ & $10.33 \pm 0.47$ & $10.17 \pm 0.24$ & $10.17 \pm 0.24$ & $9.33 \pm 0.47$ \\
\hline 5 & $10.17 \pm 0.24$ & $9.33 \pm 0.47$ & $10.17 \pm 0.24$ & $10.17 \pm 0.24$ & $9.33 \pm 0.47$ \\
\hline 6 & $10.17 \pm 0.24$ & $8.17 \pm 0.24$ & $10.33 \pm 0.47$ & $10.17 \pm 0.24$ & $9.33 \pm 0.47$ \\
\hline 7 & $10.17 \pm 0.24$ & $8.17 \pm 0.24$ & $10.33 \pm 0.47$ & $10.17 \pm 0.24$ & $9.33 \pm 0.47$ \\
\hline 8 & - & - & - & - & - \\
\hline Supernatant & $11.17 \pm 0.24$ & $9.17 \pm 0.24$ & $10.33 \pm 0.47$ & $13.17 \pm 0.24$ & $12.33 \pm 0.47$ \\
\hline
\end{tabular}

$\mathrm{d}_{\text {well }}=6.0 \mathrm{~mm}$. Inhibition zones are zones with a $\mathrm{d}>7.0 \mathrm{~mm}$ 
Acknowledgements: The research in the present study was funded by project Programme "Healthy Foods for a Strong BioEconomy and Quality of Life" approved by DCM № 577/17.08.2018, Bulgarian Ministry of Education and Science and Project "Strengthening the research excellence and innovation capacity of University of Food Technologies Plovdiv, through the sustainable development of tailor-made food systems with programmable properties“, part of the European Scientific Networks National Programme funded by the Ministry of Education and Science of the Republic of Bulgaria (agreement No D01-288/07.10.2020).

\section{References}

1. B. Timothy, A. H. Iliyasu, A. R. Anvikar, Curr. Top. Lact. Acid Bact. Probiotics 7, 1-13 (2021).

2. K. Noha, D. Nassra, M. El-Ziney, E. Kheadr, Alex. J. Fd. Sci. Technol. 18, 33-50 (2021).

3. M. N. Abdelazim (Editor), A. Mohamed, Sustainability of Agricultural Environment in Egypt: Part I: Soil-WaterFood Nexus (The Handbook of Environmental Chemistry, 76) 1st ed. Edition (Springer Nature Switzerland AG, Cham, 2019).

4. V. Verardo, A.M. Gómez-Caravaca, G. Tabanelli, Foods. 9, $153(2020)$.

5. H. S. Lade, M.P. Chitanand, G. Gyananath, T.A. Kadam, Internet J. Microbiol. 2, 13427 (2006).

6. S.D.Todorov, Braz. J. Microbiol. 39, 178-187 (2008).

7. M. Höferl, G. Buchbauer, L. Jirovetz, E. Schmidt, A. Stoyanova, Z. Denkova, A. Slavchev, M. Geissler, J. Essent. Oil Res. 21, 459-463 (2009).

8. R. Denkova-Kostova, D. Teneva, T. Tomova, B. Goranov, Z. Denkova, V. Shopska, A. Slavchev, Y. HristovaIvanova, ZNC. 76, 175-185 (2021).

9. N. Sivakumar, R. Al- Bahry Saif, Braz. Arch. Biol. Technol. 53, 1177-1184 (2010).

10. S. Todorov, L. Dicks, World J. Microbiol. Biotechnol. 20, 643-650 (2004).

11. Mezaini, N.-E. Chihib, A. D. Bouras, N. Nedjar-Arroume, J. P. Hornez, J. Environ. Public Health. 2009, 678495 (2009). 